Ann. Biol. anim. Bioch. Biophys., 1978, 18 (2 B), 399-408.

\title{
Localization and structure of nucleolar organizers in the oocyte during meiotic prophase I.
}

\author{
by A. STAHL, C. MIRRE, Michèle HARTUNG, B. KNIBIEHLER, A. NAVARRO \\ With the technical assistance of Anne de LANVERSIN and C. MORETTI (1) \\ Laboratoire d'Histologie et Embryologie II, Faculté de Médecine, \\ 27, boulevard Jean-Moulin, 13385 Marseille Cedex 4, France
}

Summary. The localization, structure and activity of nucleolar organizers were studied in quail and mouse oocytes during prophase I of meiosis using electron microscopy and in situ hybridization with tritium labelled 185 and 285 RNA.

The newly synthesized nucleolus is constituted of a fibrillar centre surrounded by a layer of electron-opaque fibrils. DNP fibres with a diameter of about $50 \AA$ extend from the nucleolar organizer to the fibrillar centre and penetrate into the latter. At the onset of nucleolar synthesis, the position of the fibrillar centre coincides with that of the ribosomal cistrons revealed by in sifu hydridization.

Following brief incorporation of tritiated uridine, labelling grains are localized over the electron-opaque fibrillar layer adjacent to the fibrillar centre.

These observations indicate that rDNA is present in both the fibrillar centre and the dense fibrillar layer which are always in association, and that transcription of the ribosomal cistrons essentially occurs in the dense fibrillar layer.

In a previous study we showed that the oocytes of birds and mammals represent particularly interesting material for studying ribosomal cistrons (Stahl et al., 1975a). In various species, de novo synthesis of nucleolar material occurs during one of the phases of meiotic prophase I. Accordingly, newly synthesized nucleoli are formed during pachytene in the quail and the mouse (Mirre and Stahl, 1976, 1978 ;-Stahl ef al., 1977). Ultrastructural studies of oocytes at this stage lead to detailed analysis of the chromosomal structures involved in nucleolar synthesis. In the quail, localization of the ribosomal cistrons in the oocyte nucleus can be identified by in situ hybridization. Comparison of the results obtained by this technique with those of the electron microscope shows that in the growing nucleolus the ribosomal genes are located in the fibrillar centre (Knibiehler et al., 1977). In human oocytes, cytological and cylogenetic techniques allowed us to demonstrate the appearance of numerous

(1) C. N. R. S. 
micronucleoli during diplotene (Stahl ef al., 1975b). This observation led us to propose the hypothetical amplification of ribosomal cistrons in the human oocyte, later confirmed by in situ hybridization (Wolgemuth-Jarashow ef al., 1977) and by electron microscopy (Luciani ef al., 1977).

The nucleolus, formed during meiotic prophase progressively displays its characteristic aspect observed in the interphase nuclei of active cells. Analysis of the stages during this evolving process should lead to an increased understanding of both the spatial configuration and the activity of the intranucleolar ribosomal genes. A new approach to these problems was attempted in this study using quail and mouse oocytes.

\section{Material and Methods.}

1. In situ hybridization. - Ovaries of 1-2, and 3-day old Japanese quails, and those of mouse embryos aged 18, 19 and 20 days (Swiss OF1) were removed and treated according to the technique of Luciani et al. (1974), i.e. fixation in methanol-acetic acid (3/1) and dissociation in 45 p. 100 acetic acid. The resulting cell suspension was spread on precooled slides which were then dried over a flame. In situ hybridization was performed using tritium labelled $18 \mathrm{~S}$ and 28S RNA, prepared from cultured Hela cells by the technique of Ascione and Arlinghaus (1970). Specific activity of the ribosomal RNA was $1.4 \times 10^{6} \mathrm{cpm} / \mu \mathrm{g}$. Hybridization performed on slides was realized according to the technique described by Gall and Pardue (1969). Preparations were coated by Kodak NTB2 emulsion, exposed for 90 days at $4{ }^{\circ} \mathrm{C}$, then developed using Kodak D19b developer, and finally stained by Giemsa's solution.

2. Electron microscopy. - Ovaries of 1-4-day old Japanese quails, those of mouse embryos aged 13 through 20 days, and ovaries of 1-, 2-, and 3-day old mice were removed. The ovaries were fixed for $15 \mathrm{~min}$. at $4^{\circ} \mathrm{C}$ by $3 \mathrm{p}$. 100 glutaraldehyde in $0.1 \mathrm{M}$ phosphate buffer, $\mathrm{pH} 7.2$, containing $0.1 \mathrm{M}$ sucrose. After washing in the buffer solution, the specimens were postfixed by 2 p. 100 osmium tetroxide in identical buffer for $20 \mathrm{~min}$. After dehydration, the ovaries were embedded in Epon and sectioned with a diamond knife in a Reichert OMU2 ultramicrotome. The sections were contrasted with uranyl acetate and lead citrate.

3. High resolution autoradiography. - Entire ovaries were incubated $30 \mathrm{~min}$. or $45 \mathrm{~min}$. at $37^{\circ} \mathrm{C}$ in $1 \mathrm{ml}$ of $80 \mathrm{p} .100$ Eagle and 20 p. 100 calf serum medium containing $100 \mu \mathrm{Ci} / \mathrm{ml}$ of $3 \mathrm{H}$-uridine (sp. act. $24 \mathrm{Ci} / \mathrm{mM}, \mathrm{CEA}$, France). After the above described fixation and before postfixation, the specimens were repeatedly washed during $30 \mathrm{~min}$. in the buffer in order to remove unincorporated radioactive uridine. After dehydration and embedding in Epon, autoradiography was performed according to the technique described by Granboulan (1965) and by Salpeter and Bachmann (1972). The sections transferred to a collodion-coated slide were stained with uranyl acetate and lead citrate. A thin carbon layer was vacuum evaporated over the stained sections. The slides were then coated with a diluted Ilford L 4 emulsion by the dipping method. After exposure for 4 months at $4^{\circ} \mathrm{C}$ the preparations were developed in Microdol-X (Kodak) for $4 \mathrm{~min}$. af $18{ }^{\circ} \mathrm{C}$ and fixed with Kodak Rapid Fixer for $3 \mathrm{~min}$. The specimen was stripped off onto a surface of double-distilled water and copper grids were 
placed over the sections. The specimens on the grid were then picked up with a filter paper. After drying, the grids were carefully released from the remnant film. The collodion film was thinned for $2 \mathrm{~min}$. in iso-amylacetate. The preparations were examined with a Siemens Elmiskop 101 microscope at $80 \mathrm{kV}$.

\section{Observations.}

\section{A. Nucleolar synthesis in the quail oocyte.}

In quail oocytes, the nucleoli are formed from the euchromatic segment of several microchromosomes having the centromeric heterochromatin contained within a chromocenter (Stahl et al., 1974). Analysis of $3 \mathrm{H}$-uridine incorporation demonstrates that the ribosomal RNAs are elaborated during middle and late pachytene, in the vicinity of numerous microchromosomes (Hartung and Stahl, 1976).

Data from electron microscopy studies in the quail nucleus show that newly synthesized nucleoli are formed during mid- and late pachytene. These data permit precise idenfification of the chromosomal structures involved in such nucleolar synthesis.

The nucleolus always appears at one extremity of a very short bivalent formed by the pairing of two microchromosomes. The other bivalent extremity is composed of centromeric heterochromatin. The latter is associated with the centromeric heterochromatin of other bivalents, thus constituting a chromocentre which is constantly in contact with the nuclear envelope (fig. 1).

In most cases, the distal end of the bivalent presents an enlargement composed of tightly packed chromatin fibres. Thin fibres which penetrate into the nucleolus can be seen emanating from the enlargement. The nucleolar region penetrated by these fibres invariably corresponds to the fibrillar centre described by Recher ef al. (1969). A zone of electron-opaque fibrils can always be seen surrounding the fibrillar centre. At the onset of its synthesis, the nucleolus is composed of only the fibrillar centre and an incomplete " corona » of electron-opaque fibrils. Granules appear at the exterior of the dense fibrillar zone at a more advanced stage. At this stage the appearance of the nucleolus corresponds to that of a natural segregation, all the while remaining in a state of active synthesis (fig. 2).

At diplotene, the nucleotus progressively takes on a reticular appearance. Multiplication of the fibrillar centres, which are no longer peripherally situated, can be seen.

Incorporation of $3 \mathrm{H}$-uridine was studied using high resolution autoradiography. Silver grains were almost always observed over the zone of electron-opaque fibrils surrounding the fibrillar centre (fig. 3).

In sifu hybridization demonstrates that 4 bivalents contain the ribosomal cistrons. Following autoradiography, silver grains are observed over the euchromatic segment of certain microchromosomes in proximity to the centromeric heterochromatin (fig. 4). This region topographically corresponds to the fibrillar centre of the developing nucleolus. 
B. Nucleolar synthesis in the mouse oocyte.

In the pachytene mouse oocyte, the centromeric heterochromatin of several bivalents can be seen to associate thus forming chromocentres. This process is quite comparable to that observed in the quail oocyte. As in the latter case, the chromocentres are in contact with the nuclear envelope. At pachytene stage, new nucleoli are formed in contact with the juxta-centromeric zone of the bivalents which are either isolated or inserted in a chromocentre.

Ultrastructural study of this phenomenon permits analysis of the chromosomal region giving rise to the nucleolus. This region corresponds to a secondary constriction and is characterized by the presence of thin chromatin fibres approximately $50 \AA$ in diameter. These fibres extend from the lateral element of the synaptonemal complex up to the fibrillar centre and penetrate into the latter (fig. 5). At the onset of nucleolar synthesis, the nucleolus is only composed of the fibrillar centre partially surrounded by a layer of electron-dense fibrils. As the nucleolus gradually develops it tends to appear band-shaped. The proximal portion of the nucleolus, facing the bivalent secondary constriction, is constituted by the fibrillar centre incompletely surrounded by dense fibrils. This proximal region is followed by a fibrillar zone of lower electron opacity and finally a fibrillo-granular zone. The distal region of the nucleolus appears essentially granular.

The nucleolus presents a reticular texture at diplotene stage. Several fibrillar centres can be observed, occupying various sites within the nucleolus. These fibrillar centres are invariably surrounded by electron-dense fibrils.

Incorporation of $3 \mathrm{H}$-uridine was studied in the light and electron microscope. After incorporation for $30 \mathrm{~min}$., light microscopy reveals labelling grains over the juxtacentromeric region of certain bivalents the heterochromatin of which generally participates in a chromocentre. High resolution autoradiography demonstrates that the silver grains are localized on the electron-dense fibrils surrounding the fibrillar centre, while the latter is unlabelled (fig. 6).

FIG. 1. - One-day old quail oocyte af pachyfene. Synthesis of nucleoli occurs in contact with a chromocentre formed by association of the centromeric heterochromatin $(\mathrm{CH})$ from several bivalents. SY : synaptonemal complex. NE : nuclear envelope ( $\times 20000)$.

FIG. 2. - One-day old quail oocyte of pachytene. The newly formed nucleolus presents a fibrillar centre (FC) into which penetrate chromatin fibres emanating from a bivalent. The fibrillar centre is partially surrounded by strands of electron-opaque fibrils (arrows). The distal part of the nucleoIus appears granular (G). SY : synaptonemal complex ; $\mathrm{CH}$ : centromeric heterochromatin ; NE : nuclear envelope ( $\times 40000)$.

FIG. 3. - Autoradiography following $3 \mathrm{H}$-uridine incorporation for $30 \mathrm{~min}$. Silver grains are located over the fibrillar strands. The fibrillar centres (arrows) are unlabelled. Two-day old quail oocyte at diplotene ( $\times 26000)$.

FIG. 4. - Autoradiography offer in situ hybridization using tritium labelled 185 and 285 RNA. In the two pachytene oocytes labelling grains (arrows) are located near a chromocentre, overlying the bivalents containing the two paired nucleolar organizers $(x 1800)$. 

In situ hybridization reveals ribosomal cistrons on a maximum of 3 bivalents. These cistrons are situated in a juxta-centromeric region which is both narrow and less highly stained than the remaining bivalent segments. The appearance and location of this region correspond to that of a secondary constriction. In some cells, the localization of labelling grains corresponds to that of the fibrillar centre (fig. 7.).

\section{Discussion.}

Our observations in quail and mouse oocytes demonstrate that fine chromatin fibres extend from the nucleolar organizer region up to the developing fibrillar centre and penetrate into the latter. The Gogliati and Gautier technique reveals that the fibrillar centre indeed contains numerous DNA fibres (Mirre and Stahl, 1978). This DNA contains ribosomal cistrons as evidenced by in situ hybridization.

The presence of DNA in the fibrillar centre of the nucleolus has been shown in various cell types : Ehrlich's tumor cells (Goessens, 1974, 1976), mouse fibroblasts (Pouchelet et al., 1975 ; Anteunis et al., 1975) and plant cells (Lafontaine and Lord, 1973 ; Lord ef al., 1977). It should be underlined that only in sifu hybridization is capable of revealing the nature of the genes in such DNA.

In agreement with the conclusions of Goessens using different study material, our observations indicate that the fibrillar centre is the site of the nucleolar organizer.

It is interesting to note that the relations between the chromosomes and fibrillar centre observed in the present study are highly similar to those reported in plant meiocytes (Jordan and Luck, 1976).

It is probable that the chromatin fibres which penetrate into the fibrillar centre form loops by taking on a spatial configuration allowing rDNA transcription to occur. This configuration has already been proposed by Baker and Franchi (1967) in human oocyte chromosomes at diplotene. Kierszenbaum and Tres (1974) showed that spermatocyte bivalents in the mouse are of the "lampbrush " type with the fibres emanating from either side of the axial region forming lateral loops.

The transcription of rDNA in the fibrillar centre is still controversial (Recher ef al., 1976). Our studies using $3 \mathrm{H}$-uridine incorporation reveal that transcription of

FIG. 5. - Nineteen-day old embryonic mouse oocyte. Synthesis of the 2 nucleoli is symmetrical in the secondary constriction region (arrows) of a bivalent the centromeric helerochromatin of which $(\mathrm{CH})$ is attached to the nuclear envelope (NE). In the secondary constriction region $50 \AA$ fibres penetrate into the fibrillar centre (FC). SY : synaptonemal complex $(\times 57000)$.

FIG. 6. - Autoradiography following $3 \mathrm{H}$-uridine incorporation for $30 \mathrm{~min}$. Labelling grains are located over the fibrillar components of the nucleolus. The fibrillar centre (arrow) is unlabelled. Oocyte of 15-day old mouse embryo $(\times 31500)$.

FIG. 7. - Mouse oocyfe at pachytene stoge. In sifu hybridization with tritium labelled ribosomal RNA. Autoradiography after 70 days exposure. The silver grains (arrows) are located near the secondary constriction. This localization corresponds to the fibrillar centre $(\times 2000)$. 


\section{$6+3 \times 3 \times$}

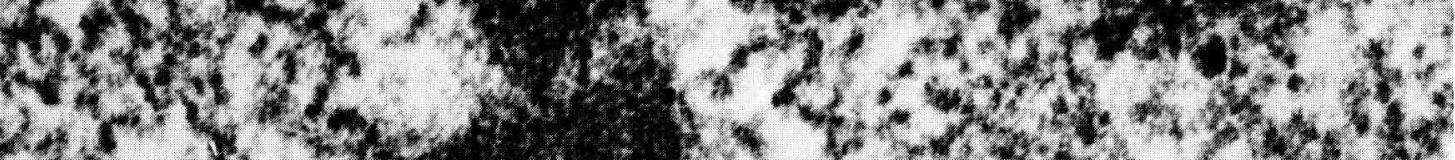

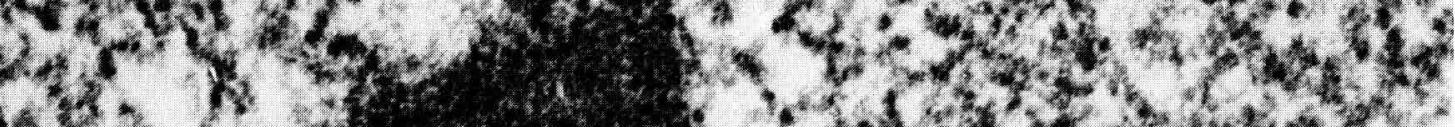

$\frac{5}{3}+2-3$

8,6 ant

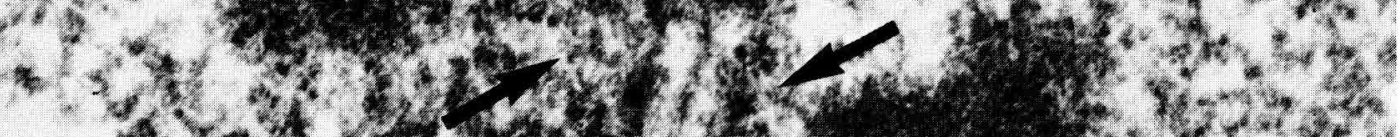

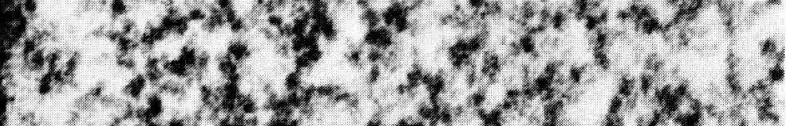

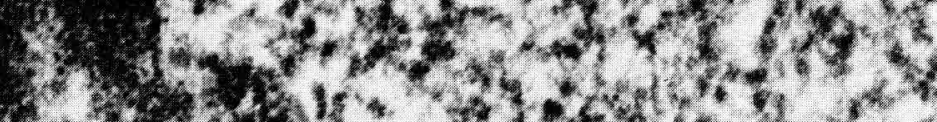

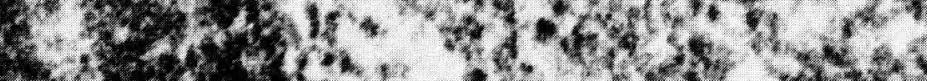

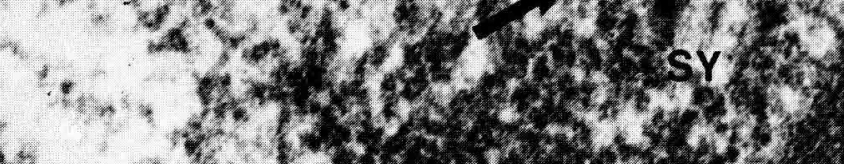

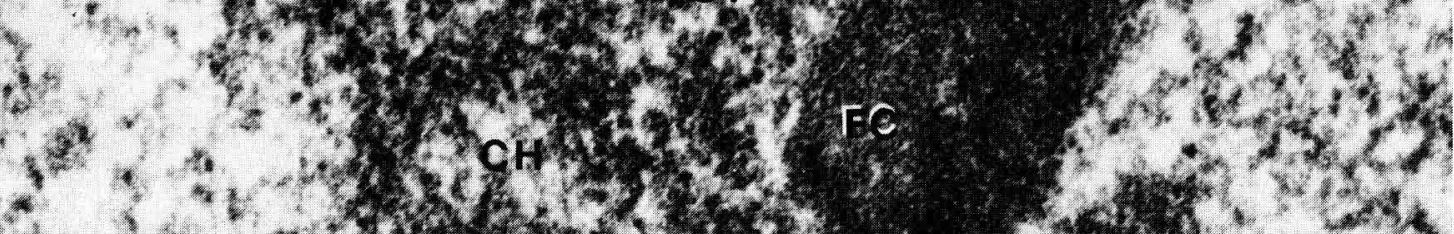

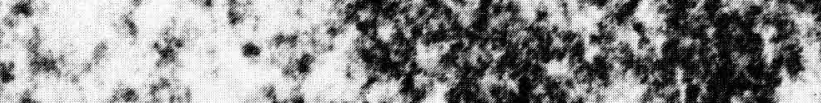

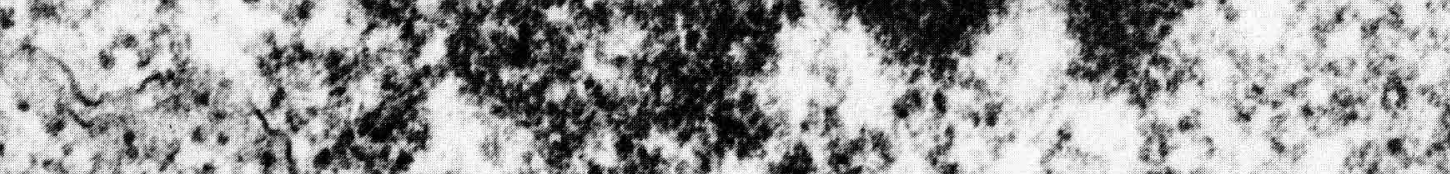

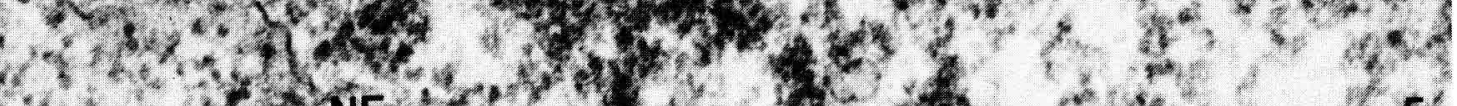

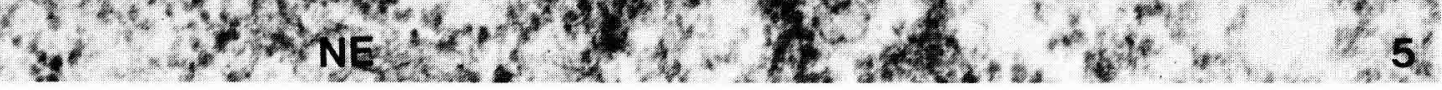
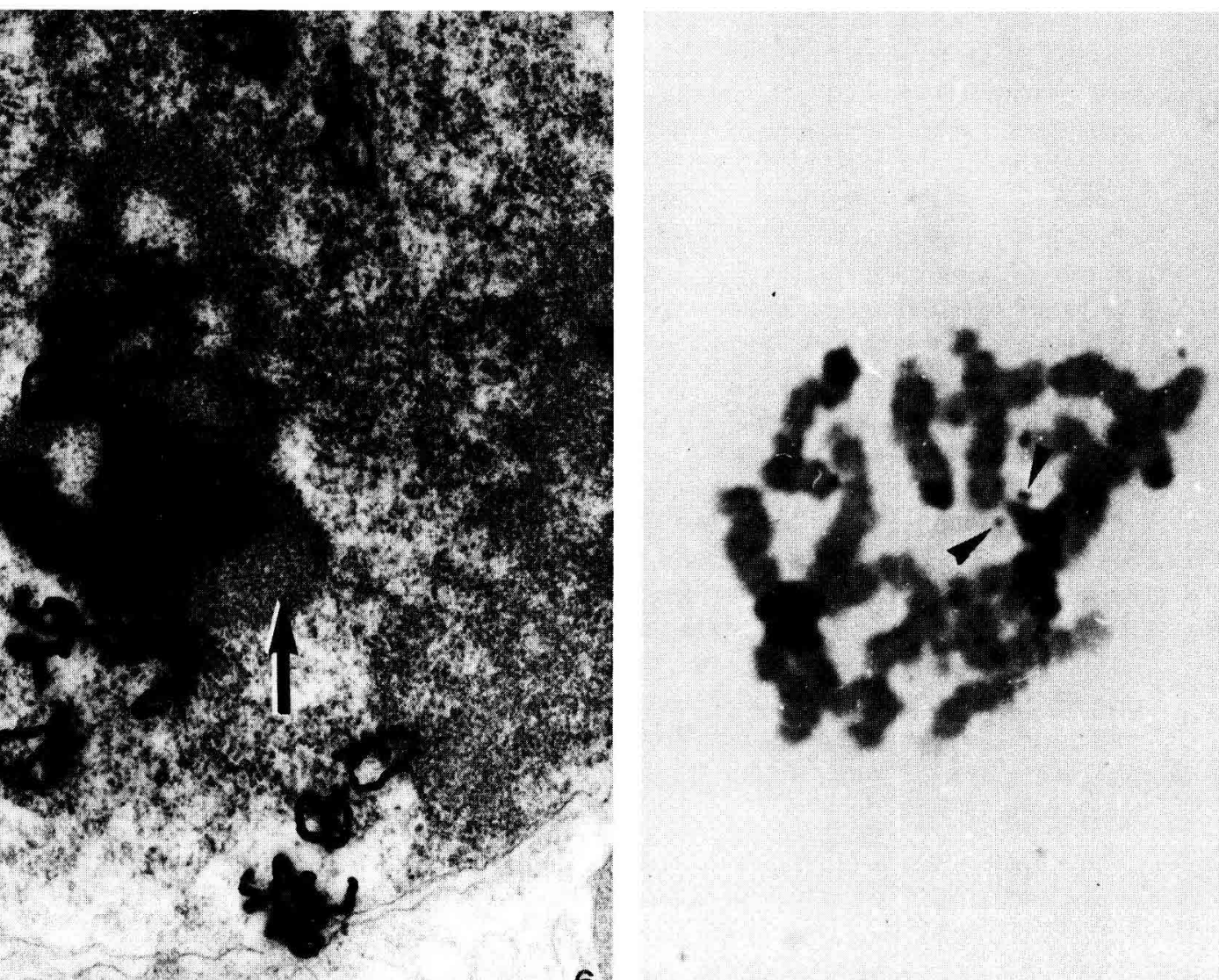
the ribosomal cistrons essentially occurs at the periphery of the fibrillar centre. A hypothetical shift of the preribosomal RNA following its transcription is difficult to accept under our experimental conditions which excluded chase after $3 \mathrm{H}$-uridine incorporation. Furthermore, since the studies of Miller and Beatty (1969) it is known that the newly synthesized RNA does not immediately detach itself from the rDNA, thus allowing visualization of the transcription units. Consequently, the localization of labelling grains must be accepted as corresponding to the transcription sites of the rDNA. This conclusion leads us to believe that the rDNA fibres emanating from the secondary constriction in the mouse oocyte or from the euchromatin of certain microchromosomes in the quail oocyte, extend through the bulk of the fibrillar centre up to its periphery. It is in this peripheral region that the rDNA is transcribed into rRNA. This notion would thus explain the presence of strands of electron-opaque fibrils directly in contact with the fibrillar centre. Accordingly, these strands would be composed of both DNA and newly synthesized RNP. Our observations thus lead to the conclusion that the fibrillar centre and its surrounding strands of electron-opaque fibrils constitute a functional unit.

Several problems nevertheless remain unresolved : on the one hand, how should we interpret the multiplicity of fibrillar centres characteristic of certain nucleoli, and secondly, how are the ribosomal cistrons arranged in those nucleoli apparently devoid of any fibrillar centre?

According to Chouinard (1971), the multiple fibrillar centres in the diplotene mouse oocyte represent transverse or oblique sections through a contorted loop of chromatin belonging to the nucleolar organizer. Serial sections of the nucleolus would be necessary to verify this hypothesis. Moreover, any model of the spatial configuration of the ribosomal cistrons must take into consideration the existence of 5 pairs of nucleolar chromosomes in the rrouse which apparently contain a variable gene number according to strain (Elsevier and Ruddle, 1975 ; Henderson ef al., 1976). If each active organizer gives rise to one fibrillar centre and if the former remains an individual unit, then the multiple fibrillar centres observed cannot be excluded as being individual entities. Certain data indicate that the nucleolar organizers may be independant of one another ; apparently this occurs most often in the peripheral zone of the nucleolus. Indeed, in human fibroblasts in situ hybridization reveals that the ribosomal cistrons are arranged in several foci at the periphery of the nucleolus and are separated from each other (Vagner-Capodano ef al., 1977).

Finally, several cell types are known to present no fibrillar centre. Following brief $3 \mathrm{H}$-uridine labeling in monkey kidney cells cultured in vitro, the silver grains corresponding to newly synthesized RNA are found in both the condensed peri- and intra-nucleolar chromatin and in the fibrillar zones of the nucleolus (Granboulan and Granboulan, 1965). In such nucleoli lacking a fibrillar centre, the ribosomal cistrons appeare to be more diffusely arranged, and this configuration may correspond to that of the fibrillar strands. The latter could be equivalent to the layer of dense fibrils which surround the fibrillar centre. Two types of arrangements of the ribosomal cistrons can thus be imagined : a) focal arrangement, evidenced by the presence of a fibrillar centre and characterized by the presence of abundant protein (Recher et al., 1969) ; b) a diffuse configuration where the rDNA would be located within the 
fibrillar strands. In this variety, the protein component is lacking. Intermediate types (many small fibrillar centres) could exist between these two extreme configurations.

$27^{e}$ Congrès international des Sciences physiologiques, Symposium "Germ and somatic cell inferaction " Paris, 21-23 juillef 1977.

Acknowledgments. - This investigation was supported by CNRS (ERA no 397) and DGRST (no 75.7.1328).

Résumé. La localisation, la structure et l'activité des organisateurs nucléolaires ont été étudiées dans les ovocytes de caille et de souris pendant la prophase méiotique, par la microscopie électronique et l'hybridation in situ par des ARN 185 et 285 marqués au tritium.

Le nucléole nouvellement formé est constiłué d'un centre fibrillaire entouré par une couche de fibrilles denses. Les fibres de DNP qui ont un diamètre de $50 \AA$ s'étendent de l'organisateur nucléolaire au centre fibrillaire et pénètrent dans ce dernier. Au débuł de la synthèse nucléolaire, la position du centre fibrillaire coïncide avec celle des cistrons ribosomiques révélés par l'hybridation in situ.

Après une brève incorporation d'uridine tritiée, le marquage est localisé sur la couche de fibrilles opaques aux électrons, adjacente au centre fibrillaire.

Ces observations indiquent que le rADN est présent à la fois dans le centre fibrillaire et dans la couche fibrillaire dense qui sont toujours associés et que la transcription des cistrons ribosomiques se produit essentiellement dans la couche fibrillaire dense.

\section{References}

ANTEUNIS A., POUCHELET M., GANSMULLER A., ROBINEAUX R., 1975. Mise en évidence ultrastructurale d'éléments sensibles à l'action de la désoxyribonucléase dans les zones fibrillaires des nucléoles des noyaux interphasiques des cellules L929. C. R. Acad. Sci. Paris, sér. D, 281, 901-903.

ASCIONE R., ARLINGHAUS R. B., 1970. Characterization and cell free activity of polyribosomes isolated from baby hamster kidney cells. Biochim. biophys. Acfa, 204, 478-488.

BAKER T. G., FRANCHI L. L., 1967. The structure of the chromosomes in human primordial oocytes. Chromosoma (Berl.), 22, 358-377.

CHOUINARD L. A., 1971. A light- and electron-microscope study of the nucleolus during growth of the oocyte in the prepuberal mouse. J. Cell Sci., 9, 637-663.

ELSEVIER S. M., RUDDLE F. H., 1975. Location of genes coding for $18 S$ and $28 S$ ribosomal RNA within the genome of Mus musculus. Chromosoma (Berl.), 52, 219-228.

GALL J. G., PARDUE M. L., 1969. Formation and detection of RNA-DNA hybrid molecules in cytological preparations. Proc. nat. Acad. Sci. (USA), 63, 378-383.

GOESSENS G., 1974. Efude autoradiographique au microscope électronique des nucléoles de cellules tumorales d'Ehrlich. Mise en évidence d'ADN au niveau des centres fibrillaires. $C$. $R$. Acad. Sci. Paris, sér. D, 279, 991-993.

GOESSENS G., 1976. High resolution autoradiographic studies of Ehrlich tumor cell nucleoli. Nucleolar labelling after ${ }^{3} \mathrm{H}$-actinomycin $\mathrm{D}$ binding to DNA or after ${ }^{3} \mathrm{H}$-thymidine or ${ }^{3} \mathrm{H}$-uridine incorporation in nucleic acids. Exp. Cell Res., 100, 88-94.

GRANBOULAN P., 1965. Comparison of emulsions and techniques in electron microscope autoradiography. In LEBLOND C. P., The use of radioaufography in investigations protein synthesis, Acad. Press, New York, IV, 43-63.

GRANBOULAN N., GRANBOULAN P., 1965. Cytochimie ultrastructurale du nucléole. II. Ełude des sites de synthèse du RNA dans le nucléole ef le noyau. Exp. Cell Res., 38, 604-619. 
HARTUNG M., STAHL A., 1976. Incorporation of tritiated uridine during pachytene and diplotene stages in the oocytes of the Japanese quail (Coturnix cofurnix japonica). Experientia, 32, 96-97.

HENDERSON A. S., EICHER E. M., YU M. T., ATWOOD K. C., 1976. Variation in ribosomal RNA gene number in mouse chromosomes. Cytogenet. Cell Genet., 17, 307-316.

JORDAN E. G., LUCK B. T., 1976. The nucleolus organizer and the synaptonemal complex in Endymion non scriptus (L.). J. cell Sci., 22, 75-86.

KIERSZENBAUM A. L., TRES L. L., 1974. Transcriptional sites in spread meiotic prophase chromosomes in the mouse testis. J. Cell Biol., 63, 923-935.

KNIBIEHLER B., NAVARRO A., MIRRE C., STAHL A., 1977. Localization of ribosomal cistrons in the quail oocyte during meiotic prophase I. Exp. Cell Res. (in press).

LAFONTAINE J. G., LORD A., 1973. An ultrastructural and radioautographic investigation of the nucleolonemal component of plant interphase nucleoli. J. Cell Sci., 12, 369-382.

LORD A., NICOLE L., LAFONTAINE J. G., 1977. Ultrastructural and radioautographic investigation of the nucleolar cycle in Physarum polycephalum. Characterization of DNA containing subunits. J. Cell Sci., 23, 25-42.

LUCIANI J. M., DEVICTOR-VUILLET M., GAGNE R., STAHL A., 1974. An air-drying method for first meiotic prophase preparations from mammalian ovaries. J. Reprod. Fert., 36, 409-411.

LUCIANI J. M., GUICHAOUA M., STAHL A., 1977. Etude ultrastructurale des processus d'élaboration nucléolaire dans l'ovocyte fotal humain en prophase I de méiose. Biol. cellul., 29, 36 a.

MILLER O. L. Jr., BEATTY B. R., 1969. Visualization of nucleolar genes. Science, 164, 955-957.

MIRRE C., STAHL A, 1976. Ultrastructural sfudy of nucleolar organizers in the quail oocyte during meiotic prophase I. J. Ultrastruct. Res., 56, 186-201.

MIRRE C., STAHL A., 1978. Cytochemical and autoradiographic studies of the quail oocyte nucleolus and nucleolar organizers during meiotic prophase I. J. Ultrastruct. Res. (submitted for publication).

POUCHELET M., GANSMULLER A., ANTEUNIS A., ROBINEAUX R., 1975. Mise en évidence en microscopie électronique, dans les noyaux interphasiques des cellules $L 299$, de filaments de DNA associés aux zones fibrillaires RNA des nucléoles. C. R. Acad. Sci. Paris, sér. D, 280, 2461-2463.

RECHER L., WHITESCARVER J., BRIGGS L., 1969. Fine structure of a nucleolar constituent. J. Ultrastruct. Res., 29, 1-14.

RECHER L., SYKES J. A., CHAN H., 1976. Further studies on the mammalian cell nucleolus. J. Ultrastruct. Res., 56, 152-163.

SALPETER M. M., BACHMANN L., 1972. Autoradiography. In HAYAT M. A., Principles abd techniques of electron microscopy. Biological applications. Van Nostrand Reinhold Co, New York, vol. 2, 221-278.

STAHL A., LUCIANI J. M., DEVICTOR, M., CAPODANO A. M., HARTUNG M., 1974. Helerochromatin and nucleolar organizers during first meiotic prophase in quail oocytes. Exp. Cell Res., 91, 365-371.

STAHL A., LUCIANI J. M., DEVICTOR M., HARTUNG M., CAPODANO A. M., MIRRE C., PARDO D., 1975a. L'ovocyte en prophase I de méiose : un modèle cyłologique pour l'étude des gènes qui codent pour les ARN ribosomiques. Ann. Biol. anim. Bioch. Biophys., 15, 697-704.

STAHL A., LUCIANI J. M., DEVICTOR M., CAPODANO A. M., GAGNÉ R., 1975b. Constifutive heterochromatin and micronucleoli in the human oocyte at the diplotene stage. Humangenetik, 26, 315-327.

STAHL A., MIRRE C., HARTUNG M., KNIBIEHLER B., NAVARRO A., 1977. Localization, structure and activity of ribosomal cistrons in the mouse oocyte during meiotic prophase I. Chromosomes to-day, vol. 6, 255-264. Elsevier-North Holland Amsterdam.

VAGNER-CAPODANO A. M., PINNA-DELGROSSI M. H., STAHL A., 1977. Localization of nucleolar organizers in the interphase nucleus of human fibroblasts. Biol. cell. 29, 209-210.

WOLGEMUTH-JARASHOW D. J., JAGIELLO G. M., HENDERSON A. S., 1977. The localization of rDNA in small, nucleolus-like structures in human diplotene oocyte nuclei. Human Genetics, 36, 63. 